have previously resulted in loss of forest, and orangutans are being injured or killed by local people. Despite this, the Indonesian Minister of Environment and Forestry has recently declared there is no possibility that the species will go extinct (Anon., 2020, foresthints.news/minister-evidenceshows-no-possibility-of-orangutan-extinction). The Ministry's optimism is not supported by our analysis of historical records of this orangutan, which indicates that the current remaining range of the Tapanuli orangutan is c. $2.5 \%$ of the range the species occupied in the 1890 os (Meijaard et al., 2020, bioRxiv, 2020.08.11.246058).

Much of this decline appears to have happened before industrial-scale deforestation for plantation development. We believe this orangutan species disappeared from much of its former range as a result of unsustainable hunting in forest that had been fragmented by land clearing for traditional agriculture.

IUCN population viability assessments indicate that an annual offtake of more than $1 \%$ of the adult population in suboptimal habitats would drive any population of this slowly reproducing great ape to extinction. Current losses are probably higher. Contrary to statements by the Minister of Environment and Forestry, we believe there is a high possibility that the species will soon go extinct unless we prevent further habitat loss and fragmentation, and ensure zero offtake.

Preventing the first potential extinction of a great ape species in recent history requires development and effective implementation of a detailed conservation action plan that applies the best science available. Such a plan will need to be endorsed by the various national and international parties involved in the area, including the Indonesian government, IUCN, funding bodies and industry.

SERGE WICH (৫ orcid.org/0000-0003-3954-5174) School of Biological and Environmental Sciences, Liverpool John Moores University, Liverpool, UK. E-mails.a.wich@ljmu.ac.uk

ERIK MEIJAARD (๑ orcid.org/0000-0001-8685-3685) Borneo Futures, Bandar Seri Begawan, Brunei Darussalam

This is an Open Access article, distributed under the Creative Commons Attribution licence CC-BY 4.0.

\section{Tourism development projects and nature loss on Xuedou Mountain, China}

Xuedou Mountain, in Ningbo in Zhejiang province, recognized as a national park since the 1980 s and one of the five renowned mountains of Buddhism in China, has been receiving more than one million visitors annually since 1991 . Covering an area of $85 \mathrm{~km}^{2}$ in the unique Danxia landform, the mountain has rich natural resources. It is a habitat for 1,600 animal species, 20 of which are threatened, as well as for plants facing a high risk of extinction, such as Eucommia ulmoides and Pteroceltis tatarinowii.

Nevertheless, 52 construction projects began in 2014, including the Buddhist Academy of Zhejiang together with temples and other places of worship. In 2018 a construction scheme comprising 12 additional projects began. The governors of Fenghua district, with representatives of other governmental institutions, announced a plan to build a village of cultural and historical significance on the mountain, aiming to boost local cultural and ecological tourism. Investments of CNY 16 billion (c. GBP 1.83 billion) were secured from companies, including China's leading real estate developer, the Evergrande Group.

This construction programme entails extensive logging, paving and construction of infrastructure, and has fragmented and damaged areas of natural habitat. The programme has also expropriated the farmland and houses of local peasants, and affected the well-being of those whose social and economic lives depend on the diminishing natural resources.

As in other scenic places, tourism to Xuedou Mountain has been affected by the COVID-19 pandemic, with all construction projects halted. But with the situation gradually brought under control, the provincial government is now taking measures to reinvigorate tourism. In April 2020 a joint meeting of the Provincial Park Association of Zhejiang and the China Association of National Parks and Scenic Sites announced a plan to revitalize the development of local tourism, with all interrupted construction projects to resume.

To reverse the adverse impacts of these projects on the local environment and communities, the Ningbo government plans to introduce a compensation policy to tackle the losses of biodiversity and attendant effects on human well-being. The policy includes ecological restoration following construction and financial compensation for affected local residents. However, without effective biodiversity offsetting, this policy is insufficient to redress the losses fully. How to offset the residual losses in one area of the mountain with commensurate gains in another area remains a challenge for the Ningbo government.

CHENTAO LI (๑ orcid.org/0000-0002-6458-2463) Department of Sociology, London School of Economics and Political Science, London, UK

SHUO GAO (৫ orcid.org/0000-0003-2239-5982)

Interdisciplinary Centre for Conservation Science, Department of Zoology, University of Oxford, UK E-mailshuo.gao@st-hildas.ox.ac.uk

\section{XIA (๑ orcid.org/0000-0003-2465-9232) Department of Management, University of Science and Technology of China, Hefei, China}

This is an Open Access article, distributed under the Creative Commons Attribution licence CC-BY 4.0. 